\title{
Penerapan Model Problem Based Learning Untuk Meningkatkan Pembelajaran IPS Tentang Kegiatan Ekonomi Pada Siswa Kelas 4
}

\author{
Khoerul Amin \\ Universitas Sebelas Maret \\ khoerulamin50@gmail.com
}

\section{Article History}

received 30/4/2021

revised 30/5/2021

accepted 30/6/2021

\begin{abstract}
.
This research is a classroom action research to improve social science learning about economic activities with the research subjects being teachers and 4th grade students of SDN 1 Tanggulangin Academic Year of 2020/2021. The application of the problem based learning model in social science learning about economic activities is applied using the following steps: 1) orienting students to problems, 2) organizing students, 3) researching, analyzing and discussing problems in a group, 4) presenting solutions and result of discussion 5) analyze and evaluate the problem solving process. The application of the problem based learning model is proven to be able to improve social science learning for 4th grade students. The learning process which includes student activity and involvement continues to increase along with the increasing success of teachers in implementing problem based learning models. The increase in the learning process also has implications for increasing student learning outcomes. So that the application of the problem based learning model is proven to be able to improve social science learning about economic activities.
\end{abstract}

Keywords: Problem based learning, learning improvement, Social science

\begin{abstract}
Abstrak
Penelitian ini merupakan penelitian tindakan kelas untuk meningkatkan pembelajaran IPS tentang kegiatan ekonomi dengan subjek penelitiannya adalah guru dan siswa kelas 4 SDN 1 Tanggulangin Tahun Pelajaran 2020/2021. Penerapan model problem based learning pada pembelajaran IPS tentang kegiatan ekonomi, diterapan menggunakan langkah-langkah sebagai berikut: 1) mengorientasikan siswa terhadap masalah, 2) mengorganisasikan peserta didik, 3) meneliti, menganalisis dan mendiskusikan masalah dalam sebuah kelompok, 4) menyajikan solusi dan hasil diskusi 5) menganalisis dan mengevaluasi proses mengatasi masalah. Penerapan model problem based learning terbukti dapat meningkatkan pembelajaran IPS pada siswa kelas 4. Proses pembelajaran yang meliputi keaktifan dan keterlibatan siswa terus meningkat seiring meningkatnya keberhasilan guru dalam menerapkan model problem based learning. Meningkatnya proses pembelajaran juga berimplikasi pada peningkatnya hail belajar siswa. Sehingga penerapan model problem based lerarning terbukti dapat meningkatkan pembelajaran IPS tentang kegiatan ekonomi.
\end{abstract}

Kata kunci: Problem based learning, peningkatan pembelajaran, IPS 


\section{PENDAHULUAN}

Berdasarkan hasil pengamatan pada siswa kelas 4 SDN 1 Tanggulangin, mendapatkan fakta-fakta seagai berikut: 1) pembelajaran masih teacher center dan kurang memicu keaktifan peserta didik 2) peserta didik kurang aktif dalam mengikuti kegiatan pembelajaran, 3) peserta didik merasa tidak semangat dan kurang antusias dalam belajar, 4) hasil belajar pada pembelajaran IPS masih banyak yang tidak mencapai batas ketuntasan dengan KKM 75. Hal tersebut disebabkan oleh beberapa faktor antara lain, 1) praktik pembelajaran yang dilaksanakan sering kali tidak mengunakan model pembelajaran ataupun pendekatan yang menarik untuk peserta didik, 2) pengunaan media pembelajaran masih jarang dilakukan, 3) pembelajaran terpusat pada guru atau teacher center.

Dibutuhkan model pembelajaran yang dapat merangsang keaktifan mengeksplorasi materi pembelajaran secara mandiri. Senada dengan pendapat Rehalat ( 2014: 10) "model pembelajaran dapat dijadikan pola pilihan dalam antrian, para guru boleh mangunakan model pembelajaran yang sesuai dan efisien untuk mencapai tujuan pendidikan". Peneliti menerapkan model problem based learning untuk meningkatkan pembelajaran IPS tentang kegiatan ekonomi pada siswa kelas 4 SDN 1 Tanggulangin tahun pelajaran 2020/2021. Keputusan tersebut mengacu pada pendapat Trianto ( 2011: 90) bahwa pembelajaran bersadarkan masalah atau problem based learning adalah suatu pembelajaran yang didasarkan pada permasalahan yang membutuhkan penyelidikan autentik yakni penyelidikan yang membutuhkan penyelesaian nyata. Kemudian diperkuat oleh pendapat Kusumawat, ( 2015: 7) "Penerapan model problem based learning untuk meningkatkan proses dan hasil pembelajaran siswa cukup efektif, terlihat dari kenaikan persentase keaktifan siswa pada setiap siklusnya".

Definisi IPS di sekolah dasar menurut Sapriya (2015: 20), adalah sejumlah konsep disiplin ilmu sosial kehidupan, seangkan materi IPS di sekolah dasar lebih meliputi dimensi paedagogik dan psikologis serta karakteristik kemampuan berpikir peserta didik yang bersifat holistic. Secara garis besar mata pelajaran IPS di sekolah dasar adalah disiplin ilmu sosial yang membahas tentang dimensi paedagogik, psikologis dan karakteristik berpikir, sehingga dapat membantu dan melatih kemampuan peserta didik agar mengenal dan menganalisis suatu persoalan yang mereka temukan di lingkungan masyarakat dari berbagai macam sudut pandang.

Tujuan mata pelajaran IPS di sekolah dasar yaitu: a) memahami konsep dalam kehidupan, b) memiliki kemampuan dasar untuk berpikir kritis dan logis, c) sadar terhadap nilai sosial dan kemanusiaan, dan d) memiliki kemampuan untuk menyatu di lingkungan masyarakat, BSNP, (2006: 254). Tujuan pembelajaran IPS adalah mengembangkan potensi peserta didik agar peka terhadap masalah yang terjadi di masyarakat, memiliki sikap mental positif dan terampil mengatasi setiap masalah yang terjadi sehari-hari baik yang menimpa dirinya sendiri maupun yang menimpa masyarakat

Model problem based learning adalah serangkaian aktivitas pembelajaran yang didasarkan pada banyaknya permasalahan yang perlu diselidiki dan diselesaikan oleh peserta didik secara ilmiah. Sesuai pendapat Trianto, (2011: 90) pembelajaran berbasis masalah merupakan suatu model pembelajaran yang didasarkan pada banyaknya permasalahan yang membutuhkan penyelidikan autentik yakni penyelidikan 
yang membutuhkan penyelesaian nyata dari permasalahan yang nyata. Pendapat yang senada dikemukakan oleh Saleh (2013: 203), pembelajaran berbasis masalah adalah metode belajar yang membelajarkan peserta didik untuk memecahkan masalah dan merefleksikan dengan pengalaman mereka, sehingga memungkinkan terjadi perkembangan keterampilan berpikir dalam memecahkan masalah yang bermakna.

Tujuan model problem based learning adalah meningkatkan kemampuan intelektual peserta didik, keterampilan berpikir dan pemecahan masalah, sehingga peserta didik memjadi pelajar yang mandiri. Hal tersebut didukung oleh pendapat Sugiyanto, (2009: 156) model problem based learning dirancang dengan tujuan untuk meningkatkan keterampilan intelektual, dan investigative, memahami peran orang dewasa dan membantu peserta didik untuk menjadi pelajar yang mandiri. Senada dengan pendapat tersebut, Trianto (2011: 94) yang menjelaskan bahwa tujuan problem based leaning yaitu: a) membantu peserta didik mengembangkan keterampilan berpikir dan keterampilan pemecahan masalah, b) belajar peranan orang dewasa, dan c) menjadi pembelajar yang mandiri.

Langkah-langkah model prolem based learning yaitu: 1) mengorientasikan siswa terhadap masalah, 2) mengorganisasikan peserta didik, 3) meneliti, menganalisis dan mendiskusikan masalah dalam sebuah kelompok, 4) menyajikan solusi dan hasil diskusi 5) menganalisis dan mengevaluasi proses mengatasi masalah.

Rumusan masalah dalam penelitian ini yaitu: 1) Bagaimana langkah-langkah penerapan model pembelajaran problem based learning untuk meningkatkan pembelajaran IPS tentang kegiatan ekonomi pada siswa kelas 4 SDN1 Tanggulangin, 2) Apakah penerapan penerapan model pembelajaran problem based learning dapat meningkatkan pembelajaran IPS tentang kegiatan ekonomi pada siswa kelas 4 SDN 1 Tanggulangin, 3) Apa kendala dan solusi dalam penerapan model pembelajaran problem based learning dalam meningkatkan pembelajaran IPS tentang kegiatan ekonomi pada siswa kelas 4 SDN 1 Tanggulangin

Adapun tujuan penelitian ini yaitu: 1) Mendeskripsikan penerapan model pembelajaran problem based learning untuk meningkatkan pembelajaran IPS tentang kegiatan ekonomi pada siswa kelas 4 SDN 1 Tanggulangin, 2) Meningkatkan pembelajaran IPS tentang kegiatan ekonomi pada siswa kelas 4 di SDN 1 Tanggulangin dengan menunakan penerapan model pembelajaran problem based learning, 3) Mendeskripsikan kendala dan solusi penerapan model pembelajaran problem based learning untuk meningkatkan pembelajaran IPS tentang kegiatan ekonomi pada siswa kelas 4 SDN 1 Tanggulangin.

Penelitian ini merupakan penelitian tindakan kelas (PTK). Prosedur pelaksanaan penelitian tindakan kelas berdasarkan Kurt Lewin (Arikunto, 2013: 131) bahwa terdiri dari empat tahap, yakni perencanaan, tindakan, pengamatan, dan refleksi. Tahap perencanaan meliputi, penyusunan skenario pembelajaran, penyusunan rencana pelaksanaan pembelajaran, menyiapkan lembar observasi guru dan siswa, dan menyiapkan panduan wawancara guru dan siswa. Tahap pelaksanaan yaitu penerapan langkah-langkah model problem based learning. Tahap pengamatan dilaksanakan bersamaan dengan pelaksanaan pembelajaran yang melibatkan observer. Tahap refleksi dilaksanakan berdasarkan hasil pengamatan observer, dan analisis hasil evaluasi peserta didik. 
Penelitian dilaksanakan di kelas 4 SDN 1 Tanggulangin, Kecamatan Klirong, Kabupaten Kebumen. Waktu penelitian dimulai bulan Januari 2021 sampai bulan April 2021 pada semester ganjil tahun pelajaran 2020/2021. Jumlah subjek penelitian yaitu 27 siswa.

Sumber data dalam penelitian ini yaitu siswa dan guru kelas SDN 1 Tanggulangin, dan dokumen. Teknik pengumpulan data yang digunakan yaitu tes, observasi, dan wawancara. Alat pengumpulan data terdiri dari lembar evaluasi, lembar observasi, dan lembar wawancara. Validitas data menggunakan teknik triangulasi sumber dan teknik.

Untuk mengukur keberhasilan penerapan model probem based learning dalam meningkatkan pembelajaran IPS tentang kegiatan ekonomi, peneliti menggunakan indikator kinerja penelitian antara lain: 1) keberhasilan guru dalam menerapkan langkah-langkah model problem based learning mencapai $85 \%$, 2) keaktifan dan keterlibatan siswa dalam proses pembelajaran mencapai $85 \%$, 3) keruntasan hasil belajar IPS tentang kegiatan ekonomi mencapai 85\% dengan KKM (75).

\section{HASIL DAN PEMBAHASAN}

Keberhasilan guru dalam menerapkan model problem based learning serta keaktifan dan keterlibatan siswa dalam diukur oleh observer mengunakan lembar observasi.

Tabel 1. Hasil Pengamatan terhadap Guru dan Siswa Soal Siklus I dan Siklus II

\begin{tabular}{ccccccc}
\hline \multirow{2}{*}{ SUBJEK } & \multicolumn{3}{c}{ SIKLUS 1 } & \multicolumn{4}{c}{ SIKLUS 2 } \\
& $\mathbf{1}$ & $\mathbf{2}$ & Rerata & $\mathbf{1}$ & $\mathbf{2}$ & Rerata \\
\hline Siswa & $67.0 \%$ & $75.0 \%$ & $71.3 \%$ & $83.5 \%$ & $87.5 \%$ & $85.5 \%$ \\
Guru & $75.0 \%$ & $80.5 \%$ & $77.8 \%$ & $83.3 \%$ & $87.1 \%$ & $85.2 \%$ \\
\hline
\end{tabular}

Bersadarkan Tabel 1 tersebut, pada siklus I keberhasilan guru dalam proses menerapkan model problem based learning mencapai $77.8 \%$, dan meningkat pada siklus II menjadi $85.2 \%$. Peningkatan juga terjadi pada keaktifan dan keterlibatan siswa dalam pembelajarannya. Pada siklus I keaktifan dan keterlibatan siswa mencapai $71.3 \%$, dan meningkat pada siklus II menjadi $85.5 \%$

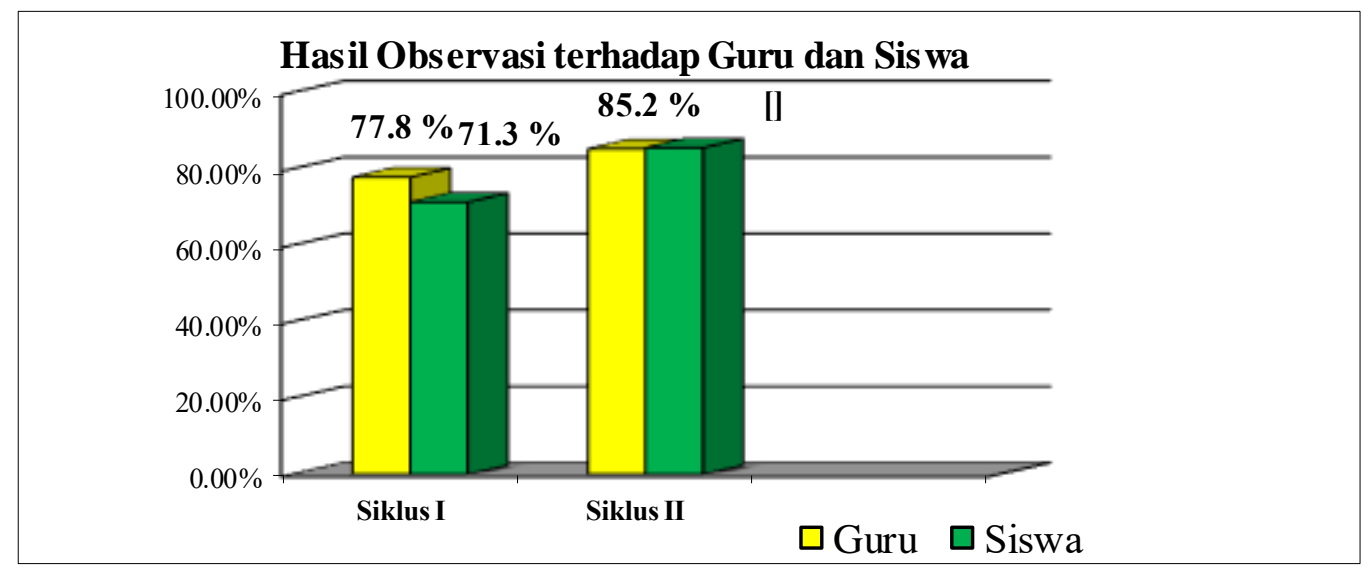

Gambar 1. Perbandingan Hasil observasi Guru dan Siswa 
Jadi, keaktifan dan keterlibatan siswa dalam proses pembelajaran dari siklus I sampai siklus II terus meningkat seiring dengan meningkatnya keberhasilan guru dalam menerapkan model problem based learning pada pembelajaran IPS tentang kegiatan ekonomi.

Tabel 2. Perbandingan Hasil Belajar Siswa Siklus I, II, III

\begin{tabular}{ccccc}
\hline Tindakan & \multicolumn{2}{c}{ Pra-Siklus } & Siklus I & \multirow{2}{*}{ Siklus II } \\
\hline Rata-rata Hasil Belajar & $70 \%$ & $74 \%$ & $79.5 \%$ & $87 \%$ \\
\hline
\end{tabular}

Sesuai Tabel 2 dengan KKM 75, presentase ketuntasan hasil belajar IPS pratindakan yaitu $70 \%$ dan $74 \%$, setelah dilakukan tindakan pada siklus I meningkat menjadi $79.5 \%$, dan meningkat kembali di siklus II menjadi $87 \%$. Hal tersebut membuktikan bahwa penerapan model problem based learning dengan media kartu soal terbukti dapat meningkatkan hasil belajar siswa pada pembelajaran IPS tentang kegiatan ekonomi.

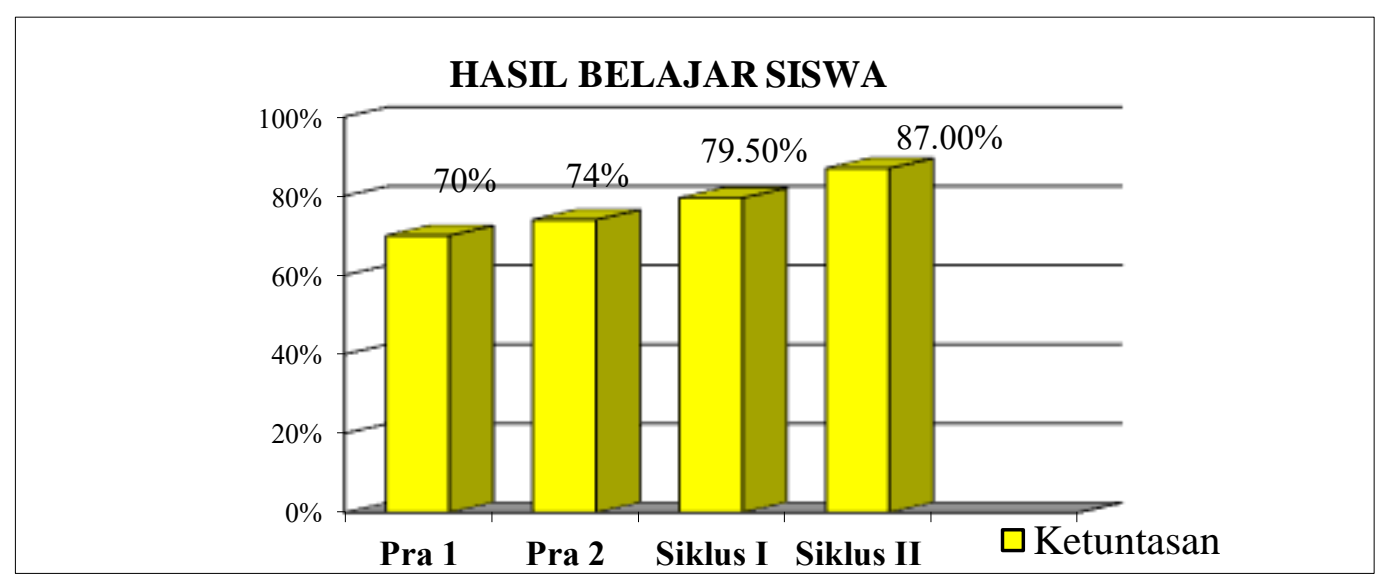

Gambar 2. Hasil belajar siswa pratindakan, siklus I dan siklus II

Berdasarkan uraian dan penjelasan di atas, proses pembelejaran dan hasil belajar siswa terus meningkat mulai dari pra-tindakan sampai tindakan siklus II. Dengan dekikian dapat disimpulkan bahwa penerapan model problem based learning dapat meningkatkan pembelajaran IPS tentang kegiatan ekonomi. Hal tersebut sesuai dengan pendapat Kusumawat, (2015: 7) bahwa "Penerapan model problem based learning untuk meningkatkan proses dan hasil pembelajaran siswa cukup efektif, terlihat dari kenaikan persentase keaktifan siswa pada setiap siklusnya".

\section{SIMPULAN}

Penerapan model problem based learning dilaksanakan dengan langkahlangkah sebagai berikut: 1) mengorientasikan peserta didik terhadap masalah, 2) mengorganisasikan peserta didik, 3) meneliti, menganalisis dan mendiskusikan masalah dalam sebuah kelompok, 4) menyajikan solusi dan hasil diskusi 5) menganalisis dan mengevaluasi proses mengatasi masalah. 
Penerapan model problem based learning dapat meningkatkan pembelajaran IPS, dibuktikan dengan meningkatnya proses dan hasil belajarnya. Presentase ketuntasan hasil belajar IPS pratindakan yaitu $70 \%$ dan $74 \%$, setelah dilakukan tindakan pada siklus I ketuntasan hasil belajar siswa menjadi $79.5 \%$, meningkat kembali di siklus II menjadi $87 \%$. Peningkatan juga terjadi pada proses pembelajaran, keaktifan dan keterlibatan siswa dalam proses pembelajaran pada siklus I mencapai $7153 \%$,dan meningkat lagi pada siklus II menjadi $85.5 \%$

Dalam penerapan model problem based learning pada pembelajaran IPS tentang kegiatan ekonomi mengamali beberapa kendala antara lain: a) kesulitan dalam menghubungkan materi dengan pengetahuan siswa, b) masih terdapat bebrapa siswa yang belum memahami peran dan tugasnya dalam kelompok, c) terdapat beberapa siswa yang tidak setuju dengan anggota kelompok yang mereka dapatkan, d) kerjasama siswa dalam kelompok masih bertumpu pada salah satu siswa, e) siswa masih kurang mandiri dalam mencari informasi, dan f) siswa kurang percaya diri dalam mempresentasikan hasil diskusi. Adapun solusi dari kendala tersebut, yaitu: a) memberikan pengertian dan motivasi untuk saling bekerja sama dan mendukung satu sama lain, b) mengunakan bahasa yang mudah dimengerti siswa, c) pembagian kelompok sebaiknya dilakukan dengan melibatkan siswa, d) memberikan apresiasi kepada siswa yang aktif bertanya maupun yang aktif menjawab pertanyaan, dan d) memberikan motivasi agar siswa aktif mencari informasi sendiri dari berbadai sumber.

Berdasarkan pembahasan di atas dapat diambi kesimpulan sebagai berikut: a) apabila diterapkan sesuai langkah-langkah yang benar, penerapan model problem based learning dapat meningkatan pembelajaran (hasil dan proses) IPS tentang kegiatan ekonomi. b) apabila diterapkan sesuai langkah-langkah yang benar, maka penerapan model prolem based learning dapat membuat siswa menjadi aktif dan antusias dalam mengikuti pembelajaran, c) Penerapan model problem based learning yang telah dilaksanakan terbukti dapat meningkatkan pembelajaran, sehingga dapat dijadikan pilihan alternatif oleh guru-guru lain.

\section{DAFTAR PUSTAKA}

Arikunto, S., Suhardjono, \& Supardi. (2008). Penelitian Tindakan Kelas. Jakarta: Bumi Aksara.

Badan Standar Nasional Pendidikan. (2006). Standar Isi untuk Pendidikan Dasar dan Menengah. Jakarta: Departemen Pendidikan Nasional.

Kusumawat, W. (2015). Penerapan Model Problem Based Learning Pada Mata Pelajaran IPS Untuk Meningkatkan Hasil Belajar Siswa Kelas VI SDN Semboro 01 Kecamatan Semboro Kabupaten Jember. OPancaran, 4 (4), 1-12.

Rehalat, A. (2014). Model Pembelajaran Pemrosesan Informasi. JPIS, urnal Pendidikan IImu Sosial, 23 (2), 1-11.

Saleh, M. (2013). Strategi Pembelajaran Fiqh Dengan Problem-Based Learning. Jurnal Ilmiah Didaktika, 14 (1), 190-220.

Sapriya. (2015). Pendidikan IPS. Bandung: PT. Remaja Rosdakarya.

Siregar, M. (2014). Penerapan Menggunakan Media Pembelajaran Media Kartu Soal Pada Mata Pelajaran Pkn Siswa Di Kelas Vii Mts Al Wasliyah Sumber Mulyo Kabupaten Labuhanbatu Utara. Jurnal Eduscience (JES), 2 (2), 16-22

Sugiyono. (2012). Metode Penelitian Kuantitatif Kualitatif. Bandung: Alfabeta

Trianto. (2011). Mendesain Model Pembelajaran Inovatif-Progresif. Jakarta: PT Bumi Aksara. 